Grantham Research Institute on Climate Change and the Environment, London School of Economics and Political Science, UK

r.e.ward@lse.ac.uk Cite this as: BMJ 2021;375:n2405 http://dx.doi.org/10.1136/bmj.n2405 Published: 06 October 2021

\title{
ESSAY
}

\section{Covid-19, climate change, and the environment: a sustainable, inclusive, and resilient global recovery}

We are at a critical moment in history, facing growing crises in climate change, biodiversity, and environmental degradation-as well as covid-19. But we also have an enormous opportunity to transform the global economy and usher in an era of greater wellbeing and prosperity, write Nick Stern and Bob Ward

\section{Nicholas Stern, IG Patel, Bob Ward}

The covid-19 pandemic has shown how vulnerable and exposed the world is to global threats. The effects of the disease and the measures that have been taken to control it have had serious consequences for lives and livelihoods. In addition to the tragic toll of illness and death, economies have been hit hard, particularly in developing countries.

Continuing to tackle the disease must be the priority, particularly by ensuring access to vaccines and treatments in all countries. Rich countries have a critical responsibility not just to safeguard their own populations but to support the distribution of vaccines to developing countries.

Every country will remain potentially exposed and vulnerable to the SARS-CoV-2 virus as long as it is able to spread rapidly through unvaccinated populations in any part of the world. Common humanity and self-interest point in the same direction.

Governments have tried to limit and reverse the economic damage through rescue and recovery packages. The rescue efforts have understandably focused on protecting existing jobs and companies, but recovery offers the chance to accelerate the transition towards a more inclusive, sustainable, and resilient form of economic development and growth.

A report prepared at the request of the British prime minister, Boris Johnson, for the G7 Leaders' Summit in Carbis Bay, Cornwall, in June 2021 laid out the case for an investment led recovery from the pandemic. ${ }^{1}$ It pointed out that an increase in annual investment of $\$ 1 \mathrm{tn}$ (£o.7tn; €o.9tn), equivalent to $2 \%$ of the collective national output, across the $\mathrm{G} 7$ countries over the coming decade and beyond would drive strong growth out of the economic difficulties arising from the pandemic and from the relatively low levels of investment, particularly since the financial crisis in 2008-9, which have been a major cause of sluggish growth in many rich countries over the past decade.

Most of this increase in investment will be made by the private sector, but governments also need to lead by example through their spending programmes both to kickstart growth and play their parts in crucial infrastructure investment, particularly in zero carbon and climate resilient energy, transport, and buildings.
The rich countries should also work to support investment in developing countries to foster sustainable, resilient, and inclusive development and growth. Most global investment in the next two decades will be in emerging markets and developing countries, and the nature of that investment will shape the future for us all in terms of wellbeing and its sustainability.

These investments in both developed and developing countries should aim both to reduce greenhouse gas emissions and to improve resilience against the effects of climate change that cannot now be avoided. Many relevant investments spur development, reduce emissions, and strengthen resilience. There are examples across all sectors: protecting and restoring mangroves; restoring degraded land; expanding and protecting forests; improving public transport; installing decentralised solar energy systems; and constructing and retrofitting buildings to make them more efficient and resilient. All of these can boost economic development, climate change mitigation, and adaptation.

Central to these changes will be extra finance, much of it concessional, from the national and multilateral development banks. This will be crucial to reducing and managing risk for both private and public investment. The scale of the challenge implies that its scale must be expanded.

\section{Growing effects of climate change}

The growing consequences of climate change have been all too visible across the world this year with severe heatwaves, floods, wildfires, and tropical cyclones. A new assessment of the science by the Intergovernmental Panel on Climate Change (IPCC), published in August 2021, concluded that there is now a clear link between rising greenhouse gas concentrations in the atmosphere and increases in the frequency and intensity of extreme weather events. ${ }^{2}$ It states: "Climate change is already affecting every inhabited region across the globe, with human influence contributing to many observed changes in weather and climate extremes.”

Although the IPCC's review of the effects of climate change on people and wildlife is not due to be published until next year, losses are clearly mounting around the world. One of the great injustices of climate change is that the poorest people around the 
world are often most exposed and vulnerable to the effects, even though they are least responsible for the driving cause: the rise in concentrations of carbon dioxide and other greenhouse gases in the atmosphere.

The most recent Human Development Report, ${ }^{3}$ published by the United Nations Development Programme in December 2020, pointed out that climate change has played a large role in reducing average incomes, particularly in low income countries, increasing the number of people experiencing hunger and expanding the number of people affected by climate and weather disasters.

Climate change has been making it more difficult to achieve many of the United Nations Sustainable Development Goals (SDGs), even before the pandemic. In his 2021 annual progress report on the SDGs, ${ }^{4}$ the United Nations secretary general, António Guterres, said: "The pandemic related economic downturn has pushed between 119 and 124 million more people into extreme poverty in 2020, further compounding challenges to poverty eradication such as conflict, climate change, and natural disasters."

The mounting damage from climate change is clearly harming efforts to overcome poverty and raise living standards, particularly in developing countries. Global mean surface temperature is already more than $1^{\circ} \mathrm{C}$ above its pre-industrial level. A special report by the IPCC in October 2018 provided a detailed review of the evidence about the risks of warming exceeding $1.5^{\circ} \mathrm{C} .5^{5}$ There is a growing consensus that those risks pose an unacceptable threat.

The IPCC report concluded that, to prevent warming exceeding $1.5^{\circ} \mathrm{C}$ by the end of the century, greenhouse gas emissions would need to be cut sharply over the coming decades, with net carbon dioxide emissions reduced to zero by 2050-this means that any residual emissions from human activities would need to be compensated by equivalent removals from the atmosphere by planting more vegetation or through other artificial methods involving carbon capture, use, and storage. Many countries have now pledged to reach net zero annual emissions of greenhouse gases by 2050.

\section{New form of economic development and growth}

Greater understanding of the urgency required to cut emissions has been accompanied by mounting evidence that it does not mean sacrificing economic development and growth. Annual emissions by the United Kingdom, for example, fell by 43.8\% between 1990 and $2019,{ }^{6}$ whereas its gross domestic product rose by $78 \%$ over the same period. 7 This is a critically important insight, particularly for developing countries that understandably view economic growth as essential to improving the lives of their citizens. The increase in economic activity is usually accompanied by more jobs, higher incomes, and less hunger, as well as potentially higher tax revenues for governments to invest in public services, including health and education.

Some people argue that greenhouse gas emissions can only be eliminated by killing economic growth. But this is analytically incorrect. There is nothing inherent about economic growth that requires emissions. Energy can be generated from sources other than fossil fuels, which are the main driver of emissions.

Furthermore, commitment to the new path for economic development and growth is already generating rapid innovation and cost reduction for most countries. Round-the-clock renewable electricity is now cheaper than fossil fuel electricity in many places, for example. Electric vehicles are more efficient than those driven by internal combustion engines. Resource efficiency (including the circular economy) improves productivity. And progress is rapid.
As countries emerge from the pandemic, investments in the rapid transition away from fossil fuels towards cleaner sources of energy will have multiple economic benefits. It will, for example, drastically reduce the number of deaths from air pollution, which kills more than seven million people worldwide every year, according to the World Health Organization, ${ }^{8}$ and knocks several percentage points off economic output, ${ }^{9}$ particularly in countries like China and India.

Investments in sustainable infrastructure, such as renewable energy and electric trains, can improve the economic competitiveness of countries and transform cities into more attractive places where people can live, move, and breathe more easily. Infrastructure that is not sustainable has the opposite effect-creating more pollution, waste, and congestion.

An investment led recovery that accelerates the transformation to sustainable, inclusive, and resilient economic development and growth will not only avoid the worst potential consequences of climate change, biodiversity loss, and environmental degradation, but will also create meaningful job opportunities and improve the lives of people around the world. A new form of clean, sustainable, efficient and inclusive development and growth is now in our hands. It will involve strong investment and some dislocation. It is important that the transition is, and is seen to be, just. All this will require strong commitment and leadership. But if offers us a much better future.

\section{Biographies}

Nick Stern is a cross bench member of the UK House of Lords. He has been president of the British Academy, the Royal Economic Society, and the European Economic Association. He was head of the UK Government Economic Service from 2003 to 2007 and head of the Stern Review on the Economics of Climate Change, published in 2006. He was chief economist of the European Bank for Reconstruction and Development between 1994 and 1999, and chief economist and senior vice president at the World Bank between 2000 and 2003.

Robert Ward is deputy chair of the London Climate Change Partnership and a fellow of the Geological Society, the Royal Geographical Society, and the Energy Institute. He was previously director of public policy at Risk Management Solutions between 2006 and 2008, and senior manager for policy communication at the Royal Society between 1999 and 2006. He has also worked as a freelance science journalist

Commissioned, not externally peer reviewed.

Competing interests: We have read and understood BMJ policy on declaration of interests and declare the following: NS oversaw the preparation of the G7 report by the Grantham Research Institute on Climate Change and the Environment, which he has chaired since its foundation in 2008, and RW. who has been policy and communications director at the institute since its foundation, was one of the writing team

Stern N. G7 leadership for sustainable, resilient, and inclusive economic recovery and growth: An independent report requested by the UK Prime Minister for the G7. London: Grantham Research Institute on Climate Change and the Environment. June 2021.

https://www.lse.ac.uk/granthaminstitute/publication/g7-leadership-for-sustainable-resilient-andinclusive-economic-recovery-and-growth/.

2 Intergovernmental Panel on Climate Change. Climate change 2021: the physical science basis. 2021. https://www.ipcc.ch/report/ar6/wg1/\#FullReport

3 United Nations Development Programme. Human development report 2020. 2020 http://hdr.undp.org/en/2020-report

4 United Nations Secretary-General. Progress towards the Sustainable Development Goals: report of the secretary-general. 30 April 2021. https://unstats.un.org/sdgs/files/report/2021/secretarygeneral-sdg-report-2021--EN.pdf

Intergovernmental Panel on Climate Change. Global warming of $1.5^{\circ} \mathrm{C}: 2018$. https://www.ipcc.ch/sr15/

6 Department for Business, Energy, and Industrial Strategy. 2019 UK greenhouse gas emissions, final figures. 2021. https://assets.publishing.service.gov.uk/government/uploads/system/uploads/attachment_data/file/957887/2019_Final_greenhouse_gas_emissions_statistical_release.pdf 
7 Office for National Statistics. Gross domestic product: chained volume measures: seasonally adjusted fm. 2021. https://www.ons.gov.uk/economy/grossdomesticproductgdp/timeseries/ab$\mathrm{mi} / \mathrm{pn} 2$

8 World Health Organization. Air pollution. 2021. https://www.who.int/health-topics/air-pollution\#tab=tab_1

9 World Bank, Institute for Health Metrics and Evaluation. The cost of air pollution: strengthening the economic case for action. 2016. https://documents1.worldbank.org/curat-

ed/en/781521473177013155/pdf/108141-REVISED-Cost-of-PollutionWebCORRECTEDfile.pdf

This article is made freely available for use in accordance with BMJ's website terms and conditions for the duration of the covid-19 pandemic or until otherwise determined by BMJ. You may use, download and print the article for any lawful, non-commercial purpose (including text and data mining) provided that all copyright notices and trade marks are retained. 